\title{
Biochemical studies of amylase, lipase and protease in Callosobruchus maculatus (Coleoptera: Chrysomelidae) populations fed with Vigna unguiculata grain cultivated with diazotrophic bacteria strains
}

\author{
L.B. Silva ${ }^{1 *}$, É.B. Torres ${ }^{1}$, R.A.S. Nóbrega ${ }^{2}$, G.N. Lopes ${ }^{1}$, \\ R.F. Vogado ${ }^{1}$, B.E. Pavan ${ }^{3}$ and P.I. Fernandes-Junior ${ }^{4}$ \\ ${ }^{1}$ Graduate Program in Agronomy-Crop Science, Federal University of
} Piaui - Cinobelina Elvas Campus, Municipal Highway Bom Jesus - Viana, Km 03 Bom Jesus, PI 64900-000, Brazil: ${ }^{2}$ Federal University of Recôncavo da Bahia (UFRB), Center for Agrarian, Environmental and Biological Sciences

(CCAAB), Rua Rui Barbosa 710, Centro, Cruz das Almas, BA, Brazil:

${ }^{3}$ Departament of Plant Science Socio-Economics and Food Technology of Ilha Solteira UNESP-FEIS Faculty of Engineering, State University of São Paulo,

P.O. Box 31, Ilha Solteira, SP 15385-000, Brazil: ${ }^{4}$ Embrapa Semiarido,

Petrolina, Pernambuco, Brazil

\begin{abstract}
The objective of this study was to evaluate the enzymatic activity of homogenates of insects fed on grain of cowpea, Vigna unguiculata (L.), cultivars grown with different nitrogen sources. For the experiment we used aliquots of the homogenate of 100 unsexed adult insects, emerged from $10 \mathrm{~g}$ of grain obtained from four cowpea cultivars: 'BRS Acauã', 'BRS Carijó', 'BRS Pujante', and 'BRS Tapaihum' grown under different regimes of nitrogen sources: mineral fertilizer, inoculation with strains of diazotrophs (BR 3267, BR 3262, BR 3299; INPA 03-11B, 03-84 UFLA, as well as the control (with soil nitrogen). The parameters evaluated were enzymatic activities of insect protease, amylase and lipase and the starch content of the grains. There were differences in the enzymatic activity of amylase, lipase and protease of insect homogenate according to the food source. A lower activity of the enzyme amylase from $C$. maculatus homogenate was observed when insects were fed grain of the cultivar BRS Carijó. A lower activity of lipase enzyme from C. maculatus homogenate was observed when the insects fed on grain from the interaction of the cultivar Tapaihum inoculated with BR 3262 diazotrophs. The lowest proteolytic activity was observed in homogenate of insects fed on interaction of 'BRS Carijó' inoculated with BR 3262 diazotrophs. Starch content correlated positively with the amylase activity of $C$. maculatus homogenate. The cultivar BRS Carijó had a different behavior from the other cultivars, according to the cluster analysis.
\end{abstract}

Keywords: nitrogen fertilization, nitrogen fixation, digestive enzyme, cowpea weevil, carbohydrate metabolism

*Author for correspondence

Phone: +55 89 9992-43847

Fax: +55 $893562-1929$

E-mail: lubarbosabio@hotmail.com 
(Accepted 13 March 2017; First published online 9 May 2017)

\section{Introduction}

Cowpea plays a vital role as a source of livelihood for millions of people in northeast Brazil. From its production, rural families derive food, animal feed, and cash income. It provides nutritious grain and an inexpensive source of protein for both rural poor and urban consumers. Cowpea grain contains about $25 \%$ protein and $64 \%$ carbohydrate (Chinma et al., 2008). In terms of poverty effects, food legumes, especially cowpea in northeast Brazil offers tremendous potential to contribute to the alleviation of protein malnutrition among resource-poor farmers. In addition, cowpea contributes to the sustainability of cropping systems and soil fertility improvements in marginal lands by providing ground cover and plant residues, fixing nitrogen, and suppressing weeds. However, the presence of insects during storage is said to decrease the quality of stored cowpea. Thus, to satisfy future human food demands, adaptive and strategic research of pulse crops remains necessary; especially to select the best suited varieties with acceptable levels of resistance to insect attack.

As an alternative to increase the yield of cowpea and lower production costs, especially in relation to nitrogen fertilizers, it has been that nitrogen fixation, by diazotrophic bacteria may be an alternative to replace nitrogen fertilizers (Lacerda et al., 2004; Soares et al., 2006; Almeida et al., 2010; Costa et al., 2011; Ferreira et al., 2013).

Among the problems associated with cowpea cultivation, insect pests are of economic importance, affecting the various stages of crop development in the field and during storage, causing qualitative and quantitative damage to the grain. The cowpea weevil, Callosobruchus maculatus Fabr. (Coleoptera: Chrysomelidae: Bruchinae), is the most important pest of stored cowpea grain, Vigna unguiculata (L.), reducing the quality and commercial value of the product (Sousa et al., 2005). The damage is the result of penetration and feeding of the larvae within the seeds, causing weight loss and reducing germination, the nutritive value of the cowpea grain, and the degree of product, due to the presence of droppings, eggs and pests secondary to storage (Almeida et al., 2005).

The control of C. maculatus, as well as other insect pests associated with stored grain, has been conducted on a large scale using chemical fumigants such as phosphine, organophosphates and pyrethroids (Benhalima et al., 2004). The increase in knowledge of the losses arising from the indiscriminate use of these products and consumer concerns about food quality have encouraged research related to new techniques for pest control, for example trypsin inhibitors in cowpea (Tavares \& Vendramim, 2005; Wang et al., 2014).

The use of cultivars that have some sort of genetic resistance to this insect is a promising method to control C. maculatus, optimizing production and reducing costs and post-harvest losses (Boyer et al., 2012). One should also consider that different sources of nitrogen in legumes such as mineral fertilizer or inoculated with symbiotic diazotrophic gram negative bacteria effects on the behavior and biology of C. maculatus (Silva et al., 2014).

The diet of pest insects may interfere with their behavior, physiology and ecology. The insect pests of stored grain are exposed to a diet rich in polysaccharides (starch) and depend on the effectiveness of their amylases for survival (Mendiola-Olaya et al., 2000). In insects, as in other organisms, lipids play diverse roles in metabolism, are constituents of cellular structures, act as hormones and form important energy reserves in situations of high metabolic demand, such as flight and egg production (Arrese \& Soulages, 2010). In this context, the study of the enzymatic activity of $C$. maculatus may explain the resistance or susceptibility of this species to the grains of different cultivars of Vigna unguiculata, considering that amylase, proteases and lipases are enzymes that are important in digestion.

The objective of this study was to evaluate the energy metabolism and digestive enzymes of insects fed on grain of different cultivars of Vigna unguiculata grown using different sources of nitrogen.

\section{Materials and methods}

Four cultivars of cowpea, 'BRS Acauã', 'BRS Carijó', 'BRS Pujante' and 'BRS Tapaihum' (Marinho, 2014), were used in the study. Seeds were inoculated with the rhizobium inoculant strains recommended for cowpea in Brazil, in accordance with normative instruction No. 13 of 25 March 2011 - Ministry of Livestock Agriculture and Supply, BR 3267 (SEMIA 6463), BR 3262 (SEMIA 6464), BR 3299; INPA 03-11B (SEMIA 6462) or 03-84 UFLA (SEMIA 6461). In addition to the inoculant treatments, two control treatments were used, namely, ammonium sulfate ( $80 \mathrm{~kg}$ Nha- 1 applied twice, one at planting and another 30 days after emergence) and the control without fertilization or inoculation. The field experiment was conducted at the Mandacaru Experimental Station in Juazeiro, BA, Brazil; on the premises of Embrapa Semiarido (CPATSA).

The harvested grains were placed in plastic bags at a temperature of $-20^{\circ} \mathrm{C}$ (freezer) for 15 days, to eliminate any insect infestations. Before of the bioassays, the grain was removed from the freezer, placed in plastic containers covered with thin "Voile" tissue and kept in the laboratory for 6 days.

\section{Breeding of Callosobruchus maculatus}

The bioassay was conducted in plastic containers $10 \mathrm{~cm}$ in diameter and $6 \mathrm{~cm}$ in height. The plastic containers were perforated and covered in "Voile" type tissue to facilitate ventilation inside. In each container $10 \mathrm{~g}$ of cowpea from each treatment and 20 non-sexed adult insects, ranging in age from 1-5 days, were placed and allowed to oviposit in the grains each treatment. After oviposition the adults were removed from the containers. After the emergency 100 nonsexed adults were removed from each treatment and stored in plastic bags in a freezer at $-20^{\circ} \mathrm{C}$, for the analysis of enzymatic activities.

\section{Enzyme assays}

Random samples of 100 unsexed adult insects from each treatment (grain) were dipped in $1.5 \% \mathrm{KCl}$ and homogenized in $6.0 \mathrm{ml}$ of distilled water at $\mathrm{pH} 3.0$ and then macerated. The homogenate was filtered through cotton gauze and centrifuged at 10,000 gmax for $20 \mathrm{~min}$. The precipitate was discarded and aliquots of the supernatant (enzyme extract) 
Table 1. Analysis of variance of the enzymatic activity of lipase, amylase and protease from Callosobruchus maculatus, fed on grain of cowpea cultivars grown with strains of nitrogen-fixing bacteria and two controls, with and without addition of mineral nitrogen, and starch and nitrogen content of the reference grain.

\begin{tabular}{|c|c|c|c|c|c|c|}
\hline $\begin{array}{l}\text { Source of } \\
\text { variation }\end{array}$ & G.L. & $\begin{array}{l}\text { Lipase } \\
\text { (IUmg }{ }^{-1} \text { protein) }\end{array}$ & $\begin{array}{l}\text { Amylase } \\
\mathrm{AU} \mathrm{dl}^{-1} \mathrm{mg}^{-1} \text { protein) }\end{array}$ & $\begin{array}{l}\text { Protease } \\
\left(\Delta \text { abs.mg }^{-1} \text { protein }\right)\end{array}$ & $\begin{array}{l}\text { Starch } \\
\text { content }\end{array}$ & $\begin{array}{l}\text { Nitrogen } \\
\text { content }\end{array}$ \\
\hline Cultivar $^{1}$ (C) & 3 & $129,8^{\mathrm{NS}}$ & $105622,9 * *$ & $0,0699 * *$ & $79,8^{* *}$ & $13,98^{\mathrm{NS}}$ \\
\hline $\mathrm{NS}^{2}$ & 6 & $812,1^{* *}$ & $633,9^{\mathrm{NS}}$ & $0,1199^{* *}$ & $1,55^{* *}$ & $88,23^{*}$ \\
\hline Error & 84 & 201,4 & 294,4 & 0,0075 & 0,289 & 38,45 \\
\hline CV\% & & 29,47 & 6,05 & 15,6 & 1,03 & 15,61 \\
\hline Mean & & 48,17 & 283,3 & 0,556 & 51,85 & 39,72 \\
\hline
\end{tabular}

Bom Jesus-PI, 2013.

**, *, NS, significant at $1 \%, 5 \%$ and not significant, respectively by $F$ test. Means followed by the same letter in the column do not differ significantly by the Duncan test at $5 \%$ probability.

${ }^{1}$ Cowpea cultivars: BRS Acauã, BRS Carijó, BRS Pujante, BRS Tapaihum.

${ }^{2}$ Nitrogen source: strains of diazotrophic bacteria-BR 3262, BR 3267, UFLA 03-84, INPA 0311B, BR 3299, nitrogen mineral-C/N and soil nitrogen control.

were taken for determination of protein concentration by the method of Bradford (1976) to assess the activity of C. maculatus lipase, amylase and protease.

To determine the levels of amylase and lipase a BIOCLIN kit (QUIBASA - Química Básica Ltda, Belo Horizonte, Minas Gerais, Brazil) containing substrate and a color reagent was used. The reaction is based on fixed time kinetics (Caraway). The enzyme extract was incubated with the starch substrate and the reading was performed at a wavelength of $660 \mathrm{~nm}$ for amylase. The kit contained buffer, enzyme inhibitor, color reagent, substrate and acetone. For lipase, the readings were at $410 \mathrm{~nm}$ wavelength.

For total protease activity, $2 \%(\mathrm{w} / \mathrm{v})$ azocasein substrate was used in $0.1 \mathrm{M}$ Tris- $\mathrm{HCl}$ buffer, $\mathrm{pH} 8.0,37^{\circ} \mathrm{C}$. The reaction mixture consisted of $250 \mu \mathrm{l}$ of substrate and $300 \mu \mathrm{l}$ of enzyme extract, incubated at $37^{\circ} \mathrm{C}$ for $30 \mathrm{~min}$. The reaction was stopped with $1.2 \mathrm{ml}$ of $10 \%$ trichloroacetic acid (v/v) (TCA) and allowed to stand for $15 \mathrm{~min}$. on ice. Before reading at $440 \mathrm{~nm}, 1.4 \mathrm{ml}$ of $1.0 \mathrm{M} \mathrm{NaOH}$ was added.

\section{Determination of starch content in the grains}

Samples of $50 \mathrm{mg}$ grains of each treatment were triturated separately (in the knife mill). Aliquots of these samples proceeded to the analysis of starch according to methodology according to Hendrix (1993) for extraction and dinitrisalicínic acid (DNSA) for calorimetric readings (Miller, 1959).

\section{Statistical analysis}

The results were subjected to analysis of variance and the compared by $\mathrm{F}$ test and the means compared with Duncan test at $5 \%$ probability. When necessary, we proceeded to the unfolding of the interaction cultivar $\times$ nitrogen source; for such procedures the computer program SAS version 9.0, procedure PROC GLM (SAS, 2002) was used. In addition, a simple (Pearson) correlation analysis was done with the characters studied with the aid of the same computer program.

Additionally, multivariate analysis was done by calculating the mathematical distances between treatments, considering each treatment as the interaction of a cultivar with a nitrogen source, totaling 28 treatments. Distances were obtained based on means, residual variances and covariances for the five traits studied by the generalized Mahalanobis

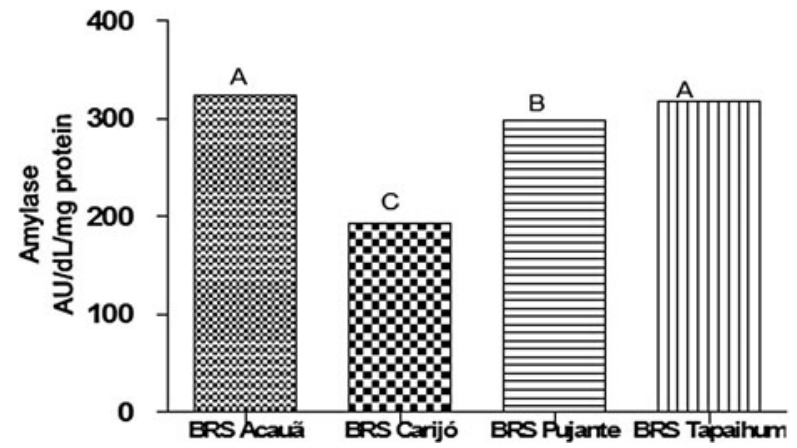

Fig. 1. Mean enzyme activity of amylase from the cowpea weevil, Callosobruchus maculatus, fed on grain of cowpea cultivars, Bom Jesus-PI, 2013.

distance, from the dissimilarity matrix done from the clustering of treatments by the UPGMA hierarchical method. These statistical procedures were performed with the aid of the GENES statistical program (Cruz, 2006).

\section{Results and discussion}

The amylase activity of Callosobruchus maculatus homogenate was significantly different between the treatments $(P<0.05)$. For the nitrogen content, there was also a difference $(P<0.05)$ between the treatments. There was an interaction $(P<0.05)$ among the cowpea cultivars: 'BRS Acauã', 'BRS Carijó', 'BRS Pujante' and 'BRS Tapaihum' and nitrogen sources for the variables: lipase, protease and grain starch content (table 1).

The greatest enzymatic activity of amylase from C. maculatus was observed when fed on 'BRS Acauã' and 'Tapaihum' (fig. 1) while the lowest enzymatic activity value was recorded when the insects fed on cultivar 'BRS Carijó'. The amylase enzyme plays a central role in carbohydrate metabolism. Organisms that have a diet rich in starch depends on the effectiveness of their amylases to survive, for example important agricultural pests that consume parts of plants rich in starch, as seeds and roots (Titarenko \& Chrispeels, 2000). The greater amylase activity correlated to the food source would involve 


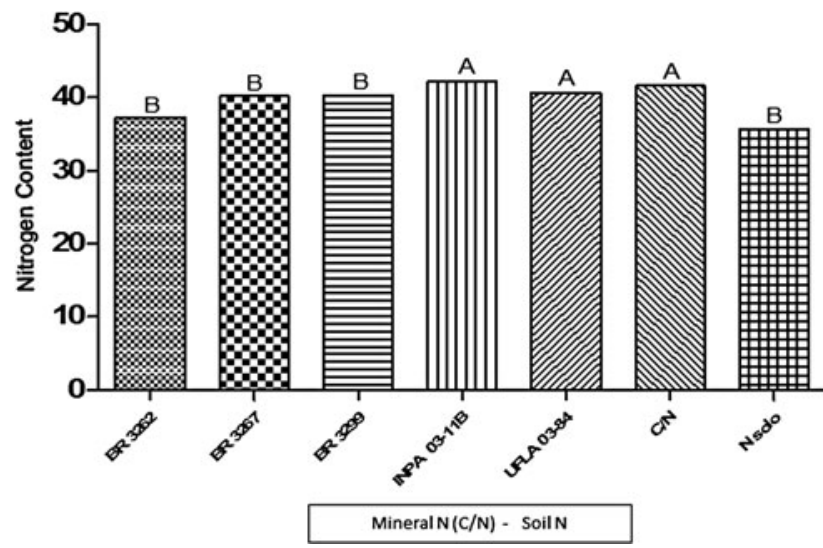

Fig. 2. Mean nitrogen content of cowpea grain from plants grown with strains of nitrogen fixing bacteria and two controls, with and without addition of mineral nitrogen. Bom Jesus-PI, 2013.

storage of available energy for survival and development animal (Luca, et al., 2010).

It is noteworthy that enzyme inhibitors constitute important mechanisms, conferring resistance in plants to pest of plants. Since the enzyme is inhibited, uptake of nutrients by insects is reduced and development affected. For example, $\alpha$ - amylase I ( $\alpha$ - AI1) inhibitor confers resistance to the common bean [Phaseolus vulgaris(L.)] against C. maculatus (Ishimoto \& Kitamura, 1989; Ishimoto \& Chrispeels, 1996) and trypsin inhibitors are responsible for antibiosis in different storage pests.

According to the results the activity of energetic and digestive metabolism enzymes of C. maculatus fed on grains produced from different sources of nitrogen, allows us to conclude that BRS 'Acauã' and 'Tapaihum' cultivars provide better metabolic conditions for growth and development. Already cultivating 'BRS Carijó', a lower metabolic efficiency, consequently lower population growth. The amylase activity in Sitophilus oryzae (L.) (Coleoptera: Curculionidae) is greater than in S. granarius (L.); therefore, S. oryzae uses more starch and grows more (Parra et al., 2009). However, low amylase activity in insects is due to the low amount of starch ingested and subsequently accumulated in fat bodies (Araújo et al., 2008).

For nitrogen content it was found that the treatments INPA 03-11B, UFLA03-84 and C/N showed the highest mean nitrogen values, differing statistically from the others (fig. 2). It is that the availability of nitrogen changes the amount of chemical constituents in the grain mass, such as the secondary metabolites and nutritional and anti-nutritional factors (Ndidi, et al., 2014; Tang, et al., 2014), being necessary chemical and nutritional studies to determine, which constituents and quantities are present in grain of the treatments analyzed here, to be able to infer how much the mechanisms of resistance of plants to the insects. Genetic manipulation and biological fixation of nitrogen may result in grain with high levels of nitrogenous metabolites thereby reducing the damage caused by bruchids. A greater quantity of available nitrogen makes possible greater production of defense molecules, such as flavonoids, alkaloids, terpenoids and sterols (compounds of secondary metabolism) (Ndakidemi \& Dakora, 2003).

The homogenate of insects fed on cultivar 'BRS Tapaihum' recorded the highest values for lipase enzymatic activity in treatments INPA $03-11 \mathrm{~B}$ and mineral nitrogen $-\mathrm{C} / \mathrm{N}$, differing statistically from the other treatments, which had lower averages.

The elevated lipase enzymatic activity of C. maculatus homogenate represents a higher energy expenditure of insects resulting in a higher growth and oviposition, these grains being favorable to the proliferation of this important pest of grain during storage, due to conditions favorable to the development of the insect (Cheng, et al., 2015). Regarding the results of lipase enzymatic activity in C. maculatus homogenate derived from 'BRS Carijó', the highest means were observed in the BR 3262, INPA 03-11B and soil N treatments (table 2).

The lowest values of lipase observed in table 2, represent a lower energy expenditure by insects in their metabolic activities, which implies reduced growth and reduced oviposition, due to lack of compounds necessary for these metabolic processes (Moghadam, et al., 2015).

Lipids are stored in the form of triacylglycerols. Many animals contain cells that are specialized in the synthesis, storage and mobilization of these triglycerides, for example, fat bodies in insects and adipose tissue in vertebrates. Triacylglycerol is hydrolyzed to glycerol and fatty acid by lipase. The glycerol produced can be converted to glyceraldehyde 3 -phosphate and then metabolized to glucose or glycogen by gluconeogenesis (Willmer et al., 2005). Gluconeogenesis is a universal pathway in all animals, plants, fungi and microorganisms, and the reactions that are part of it are the same in all cases. The major precursors of glucose in animals are lactate, pyruvate, glycerol and most of the amino acids (Lehninger et al., 2000). The decrease of carbohydrates in the cells and the reduction of blood glucose are basic stimuli that trigger increased gluconeogenesis. The reduction of carbohydrates can directly cause the reversal of many reactions of glycolysis and the phosphogluconate pathway, thus allowing the conversion of glycerol into carbohydrates (Guyton \& Hall, 1996).

Once the lipids are converted to carbohydrates in the form of glycogen, the latter is hydrolyzed by the enzyme glycogen phosphorylase, which showed no significant differences in activity between the three populations. Glycogen is then hydrolyzed, releasing trehalose, which is further metabolized by trehalase.

In insects, as in other organisms, glycogen (polysaccharide glycosidic $\alpha$ (1-4) bonds and $\alpha$ (1-6) branches every 7 or 20 residues along the main chain) is used as a glucose reserve at different points in the life cycle (Tolmasky et al., 2001). The degradation of this sugar by glycogen phosphorylase is the limiting step for the biosynthesis of trehalose (Park \& Keeley, 1996).

According to the results presented here, it appears there are oscillations associated with the change or decrease in enzymatic activity that altered the mobilizing energy sources. Thus, grains containing substances that reduce or inhibit the activity of this enzyme may be an important alternative to control pests that attack grains during storage.

For the enzymatic activity of protease, 'BRS Pujante' demonstrates significant interaction between treatments, activity being high for 'BR 3262' and 03-84 UFLA and statistically lower for the other treatments, as noted in table 3. For the cultivar 'BRS Carijó' the lowest mean enzyme activity was observed with the treatment 'BR 3262' (table 3). Research has shown that inhibition of the protease enzyme by inhibitors causes growth retardation and reduced survival rate of insects (De Leo et al., 2001; Zavala et al., 2004). Knowledge of the sensitivity of this enzyme to inhibitors is key to the development of resistant varieties. The high proteolytic activity suggests 
Table 2. Mean values of lipase enzymatic activity in the cowpea weevil, Callosobruchus maculatus, fed on grain of cowpea cultivars grown with strains of nitrogen fixing bacteria and two controls, with and without addition of mineral nitrogen.

\begin{tabular}{|c|c|c|c|c|c|c|c|}
\hline \multicolumn{8}{|c|}{ LIPASE (IUmg ${ }^{-1}$ protein) } \\
\hline${ }^{1}$ Cult $/{ }^{2}$ N.S. & BR 3262 & BR 3267 & BR 3299 & INPA 03-11B & UFLA 03-84 & $\mathrm{C} / \mathrm{N}$ & Soil N \\
\hline BRS Acauã & 50,7 Aba & 41,9 Aba & 34,5 Aa & $48,6 \mathrm{ABa}$ & $54,6 \mathrm{Aa}$ & $50,7 \mathrm{Ba}$ & 62,5 Aa \\
\hline BRS Pujante & $49,4 \mathrm{ABa}$ & $47,5 \mathrm{ABa}$ & $57,3 \mathrm{Aa}$ & $36,4 \mathrm{Ba}$ & $36,5 \mathrm{Ba}$ & $41,1 \mathrm{Ba}$ & $58,1 \mathrm{Aa}$ \\
\hline BRS Tapaihum & 31,9 Bcd & $21,5 \mathrm{Bd}$ & $39,0 \mathrm{Ac}$ & $66,1 \mathrm{Aab}$ & $29,2 \mathrm{Bcd}$ & $79,99 \mathrm{Aa}$ & $55,9 \mathrm{Ab}$ \\
\hline
\end{tabular}

Bom Jesus, PI, 2013.

Means followed by the same uppercase and lowercase letters do not differ significantly by Duncan test at $5 \%$ probability.

${ }^{1}$ Cowpea cultivars: Acauã BRS, BRS Carijó, BRS Pujante, BRS Tapaihum.

${ }^{2}$ Nitrogen source: strains of diazotrophic bacteria-BR 3262, BR 3267, UFLA 03-84, INPA 0311B, BR 3299, mineral-nitrogen C/N and soil nitrogen control.

Table 3. Mean values of protease enzymatic activity in the cowpea weevil, Callosobruchus maculatus, fed on grain of cowpea cultivars grown with strains of nitrogen fixing bacteria and two controls, with and without addition of mineral nitrogen.

\begin{tabular}{|c|c|c|c|c|c|c|c|}
\hline \multicolumn{8}{|c|}{ PROTEASE ( $\triangle$ abs.mg ${ }^{-1}$ protein) } \\
\hline${ }^{1}$ Cult $/{ }^{2}$ N.S. & BR 3262 & BR 3267 & BR 3299 & INPA 03-11B & UFLA 03-84 & $\mathrm{C} / \mathrm{N}$ & Soil N \\
\hline BRS Acauã & 0,77Aa & 0,74 Aab & 0,64 Aabc & $0,62 \mathrm{Abc}$ & 0,66 Babc & $0,54 \mathrm{Bc}$ & $0,27 \mathrm{Cd}$ \\
\hline BRS Pujante & 0,85Aa & 0,42 Bcd & $0,59 \mathrm{Ab}$ & $0,53 \mathrm{Abc}$ & 0,81 Aa & $0,35 \mathrm{Cd}$ & $0,54 \mathrm{Abc}$ \\
\hline BRS Tapaihum & $0,50 \mathrm{Bab}$ & $0,41 \mathrm{Bb}$ & $0,59 \mathrm{Aa}$ & $0,49 \mathrm{Aab}$ & $0,56 \mathrm{Ca}$ & $0,47 \mathrm{BCab}$ & $0,42 \mathrm{Bb}$ \\
\hline
\end{tabular}

Bom Jesus-PI, 2013.

Means followed by the same uppercase and lowercase column lines do not differ significantly by Duncan test at $5 \%$ probability.

${ }^{1}$ Cowpea cultivars: Acauã BRS, BRS Carijó, BRS Pujante, BRS Tapaihum.

${ }^{2}$ Nitrogen source: strains of diazotrophic bacteria-BR 3262, BR 3267, UFLA 03-84, INPA 0311B, BR 3299, mineral-nitrogen C/N and soil nitrogen control.

Table 4. Mean values for the starch content of grain of cowpea cultivars grown with strains of nitrogen fixing bacteria and two controls, with and without addition of mineral nitrogen.

\begin{tabular}{|c|c|c|c|c|c|c|c|}
\hline \multicolumn{8}{|c|}{ STARCH } \\
\hline$\overline{\text { BRS Acauã }}$ & $52,7 \mathrm{Aa}$ & $51,6 \mathrm{ABe}$ & $52,0 \mathrm{Cd}$ & $52,5 \mathrm{ABb}$ & $52,1 \mathrm{Ad}$ & $52,3 \mathrm{Cc}$ & $52,3 \mathrm{Cc}$ \\
\hline BRS Pujante & $52,4 \mathrm{Bc}$ & $52,6 \mathrm{Abc}$ & $52,5 \mathrm{Bbc}$ & $52,7 \mathrm{Ab}$ & $53,3 \mathrm{Aa}$ & $53,5 \mathrm{Aa}$ & $53,3 \mathrm{Ba}$ \\
\hline BRS Tapaihum & $52,4 \mathrm{Bbc}$ & $51,5 \mathrm{ABc}$ & $53,9 \mathrm{Aa}$ & $52,4 \mathrm{Bbc}$ & $53,5 \mathrm{Aa}$ & $53,3 \mathrm{Bab}$ & $53,5 \mathrm{Aa}$ \\
\hline
\end{tabular}

Bom Jesus-PI, 2013.

Means followed by the same uppercase and lowercase letters do not differ significantly by the Duncan test at $5 \%$ probability.

${ }^{1}$ Cowpea cultivars: Acauã BRS, BRS Carijó, BRS Pujante, BRS Tapaihum.

${ }^{2}$ Nitrogen source: strains of diazotrophic bacteria-BR 3262, BR 3267, UFLA 03-84, INPA 0311B, BR 3299, mineral-nitrogen C/N and soil nitrogen control.

Table 5. Pearson correlations (r) obtained among the variables: starch content, nitrogen content, lipase and protease, by the cowpea weevil, C. maculatus, fed on grain of cowpea cultivars grown with strains of nitrogen fixing bacteria and two controls, with and without addition of mineral nitrogen.

\begin{tabular}{llrrr}
\hline & Lipase & Amylase & Protease & Starch \\
\hline Amylase & $-0.13^{\text {ns }}$ & & & \\
Protease & $-0.19^{*}$ & $0.05^{\mathrm{ns}}$ & & \\
Starch & $-0.0001^{\mathrm{ns}}$ & $0.76^{* *}$ & $-0.07^{\mathrm{ns}}$ & \\
Nitrogen & $-0.0005^{\mathrm{ns}}$ & $-0.08^{\mathrm{ns}}$ & $0.17^{\mathrm{ns}}$ & $-0.09^{\mathrm{ns}}$ \\
\hline
\end{tabular}

Bom Jesus-PI, 2013.

$* *, *$ ns, significant at $1 \%, 5 \%$ and not significant by $t$ test, respectively. greater efficiency in the digestion of carbohydrates and proteins accumulation in the fat body cells. During the life cycle of these insects, energy reserves are allocated to maintain the defense mechanism without compromising the basic physiological processes (growth, development and reproduction), thus enabling the mitigation of the physiological costs associated with the resistance of grains of different cowpea cultivars.

As to the starch content of grain of 'BRS Acauã', the highest means were observed with the 'BR 3262', 3267 and INPA BR 03-11B treatments. For the cultivar 'BRS Carijó', the treatments 'BR 3262', 'BR 3267', C/N and Soil N showed nitrogen values superior to the rest. For 'BRS Pujante' the nitrogen treatments with the highest means were UFLA $03-84, \mathrm{C} / \mathrm{N}$ and 


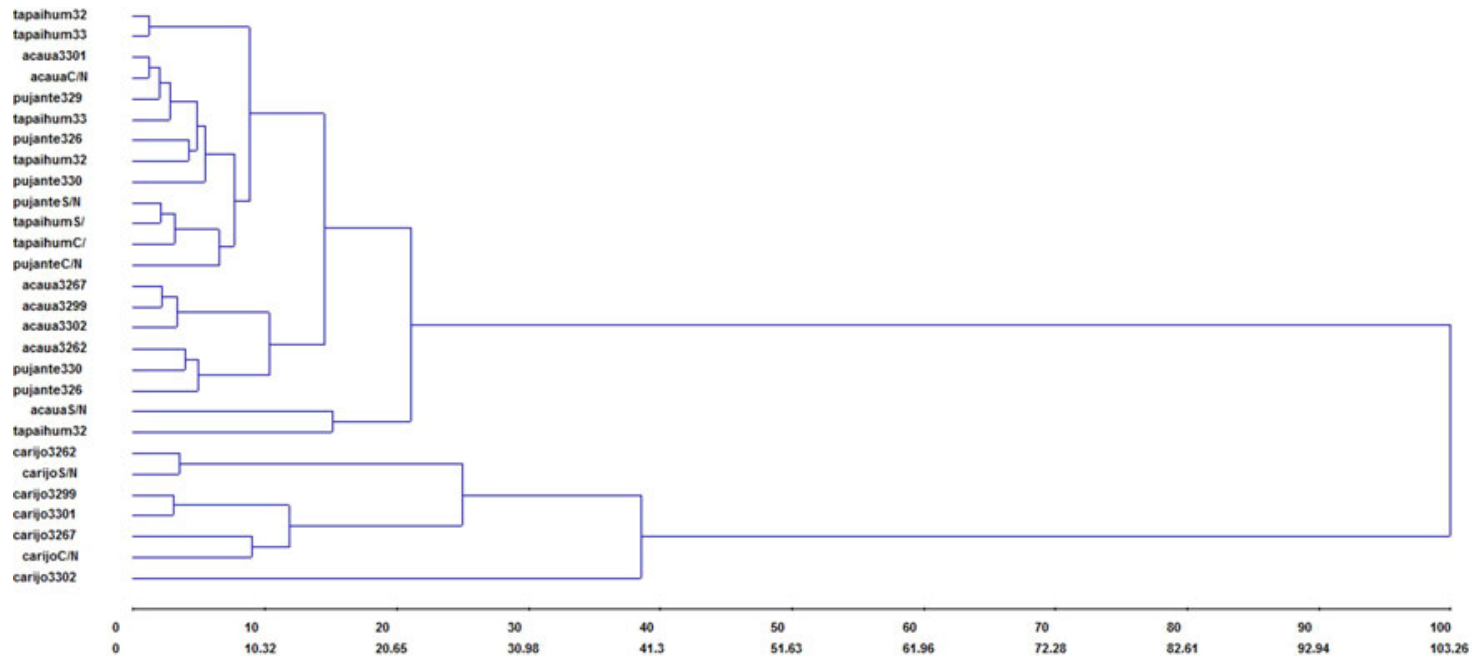

Fig. 3. Dendrogram obtained by the UPGMA method based on the matrix of mathematical distances generated by the generalized method of Mahalanobis from 28 treatments: four cultivars of cowpea, grown with five strains of bacteria fixing nitrogen and two controls (with and without addition of mineral nitrogen).

Soil N. As for 'BRS Tapaihum', the highest mean values were observed for nitrogen treatments 'BR 3299', UFLA 03-84, C/N and Soil N (table 4).

Regarding the enzymatic activity of $C$. maculatus, the results indicate a significant positive correlation between the enzymatic activity of protease and lipase (table 5). Given that protease is a digestive enzyme and lipase an enzyme of energy metabolism, it is suggested that the effectiveness of lipase depends on protease. The proteolytic activity and amylase activities also of amylase in insects suggests that during digestion large amounts of amino acids are released, which are used for protein synthesis. The proteins that are metabolized are then stored in the trophocyte cells of fat bodies of the insects and used for the growth and development of them (Guedes et al., 2006). These reserves are mobilized more efficiently because the insects showed better development. Most of the insect intermediary metabolism takes place in this organ, including lipid and carbohydrate metabolism, protein synthesis and amino acid and nitrogen metabolism. Some metabolic processes are stage specific such as the synthesis and secretion of storage proteins into the hemolymph that occur in the feeding larva or the synthesis of vitellogenin in adult insects (Arrese \& Soulages, 2010).

The starch content of the grains had a significant positive correlation with the enzymatic activity of amylase (table 5), i.e., the higher the starch ingested by insects, the greater the effectiveness of their amylases that assist in the breakdown and digestion of this nutrient.

According to the dendrogram (fig. 3), we note that only 'BRS Carijó' had a different pattern of clustering from the other cultivars. The other cultivars, despite having different groupings, were close in the dendrogram. It is noteworthy that there was no grouping pattern for the different sources of nitrogen. In overview, the dendrogram shows a different behavior for 'BRS Carijó' compared with other cultivars. That cultivar formed a divergent group, but in relation to the source of nitrogen, oscillations were observed in the combinations of nitrogen with the cultivars. Grains resulting from the interaction between cultivars and different nitrogen sources are assimilated differently by insects as demonstrated in the oscillation (variation or reduction) of the enzymatic activity of insects. Further research is needed to better elucidate the chemical or physical mechanisms present in grains that caused this behavior in the insects.

There was a difference in the enzymatic activity of amylase, lipase and protease of insect homogenate according to the food supply. The lowest activity of the enzyme amylase from C. maculatus homogenate was observed when insects were fed grain from the cultivar BRS Carijó. The lowest activity of the enzyme lipase from $C$. maculatus homogenate was observed when the insects fed on grains of the cultivar Tapaihum inoculated with BR 3262 diazotrophic bacteria.

The lowest proteolytic activity was observed in homogenate of insects fed with the cultivar BRS Carijó inoculated with BR 3262 diazotrophic bacteria. Starch content is correlated positively with the amylase activity from C. maculatus homogenate. The cultivar BRS Carijó had a different pattern of clustering from the other cultivars.

\section{Acknowledgements}

The Foundation for Research Support of the State of Piauí (FAPEPI), the Federal University of Piauí (UFPI) for the structure and for financial support.

\section{References}

Almeida, F.A.C., Almeida, A.S., Santos, N.R., Gomes, J.P. \& Araújo, M.E.R. (2005) Efeitos de extratos alcoólicos de plantas sobre o caruncho do feijão vigna (Callosobruchus maculatus). Revista Brasileira de Engenharia Agrícola e Ambiental 9, 585-590.

Almeida, A.L.G., Alcântara, R.M.C.M., Nóbrega, R.S.A., Leite, L.F.C., Silva, J.A.L. \& Nóbrega, J.C.A. (2010) Produtividade do feijão caupi cv. BR 17 Gurguéia inoculado com bactérias 
diazotróficas simbióticas no Piauí. Revista Brasileira de Ciências Agrárias 5, 364-336.

Araújo, R.A., Guedes, R.N.C., Oliveira, M.G.A. \& Ferreira, G.H. (2008) Enhanced activity of carbohydrate and lipidmetabolizing enzymes in insecticide-resistant populations of the maize weevil, Sitophilus zeamais. Bulletin of Entomological Research 98, 417-424.

Arrese, E.L. \& Soulages, J.L. (2010) Insect fat body: energy, metabolism, and regulation. Annual Review of Entomology 55, 207-225.

Benhalima, H., Chaudhry, M.Q., Mills, K.A. \& Price, N.R. (2004) Phosphine resistance in stored-product insects collected from various grain storage facilities in Marocco. Journal of Stored Products Research 40, 241-249.

Boyer, S., Zhang, H. \& Lempérière, G. (2012) A review of control methods and resistance mechanisms in stored-product insects. Bulletin of Entomological Research 102, 2013-2229.

Bradford, M.M. (1976) A rapid and sensitive method for the quantitation of microgram quantities of protein utilizing the principle of protein-dye binding. Analytical Biochemistry 72, 248-254.

Cheng, W., Lei, J., Fox, C.W., Johnston, J.S. \& Zhu-Salzman, K. (2015) Comparison of life history and genetic properties of cowpea Bruchid strains and their response to hypoxia. Journal of Insect Physiology 75, 5-11.

Chinma, C.E., Emelife, I.G. \& Alemede, I.C. (2008) Physicochemical and functional properties of some Nigerian cowpea varieties. Pakistan Journal of Nutrition 7, 186-190.

Costa, E.M., Nóbrega, R.S.A., Martins, L.V., Amaral, F.H.C. \& Moreira, F.M.S. (2011) Nodulação e produtividade de Vigna unguiculata (L.) Walp. por cepas de rizóbio em Bom Jesus, PI. Revista Ciência Agronômica 42, 1-7.

Cruz, C.D. (2006) Programa GENES, análise multivariada e simulações. Viçosa-MG, UFV, 175p.

De Leo, F., Bottino, M.B., Ceci, L.R., Gallerani, R. \& Jouanin, L. (2001) Effects of a mustard trypsin inhibitor expressed in different plants on three lepidopteran pests. Insect Biochemistry and Molecular Biology 31, 593-602.

Ferreira, L.V.M., Nóbrega, R.S.A., Nóbrega, J.C.A., Aguiar, F.L., Moreira, F.M.S. \& Pacheco, L.P. (2013) Biological nitrogen fixation in production of Vigna unguiculata (L.) Walp, Family Farming in Piauí, Brazil. Journal of Agricultural Science 5, 153160.

Guedes, R.N.C., Oliveira, E.E.; Guedes, N.M.P., Ribeiro, B. \& Serrão, J.E. (2006) Cost and mitigation of insecticide resistance in the maize weevil, Sitophilus zeamais. Physiological Entomology 31, 30-38.

Guyton, A.C. \& Hall, J.E. (1996) Textbook of Medical Physiology. 9th edn, Philadelphia, W.B. Saunders Company, 1116p.

Hendrix, D.L. (1993) Rapid extraction and analysis of nonstructural carbohydrates in plant tissues. Crop Science 33, 1306-1311.

Ishimoto, M. \& Chrispeels, M.J. (1996) Protective mechanism of the Mexican bean weevil against high levels of $\alpha$-amylase inhibitor in the common bean. Plant Physiology 111, 393-401.

Ishimoto, M. \& Kitamura, K. (1989) Growth inhibitory effects of an $\alpha$-amylase inhibitor from kidney bean, Phaseolus vulgaris (L.) on three species of bruchids (Coleoptera: Bruchidae). Applied Entomology and Zoology 24, 281-286.

Lacerda, A.M., Moreira, F.M.S., Andrade, M.J.B. \& Soares, A.L.L. (2004) Efeito de estirpes de rizóbio sobre a nodulação e produtividade do feijão caupi. Revista Ceres, 51, 67-82.

Lehninger, A.I., Nelson, D.I. \& Cox, M.M. (2000) Principles of Biochemistry. 3rd edon, New York, Worth Publishers Inc., 1200p.

Luca, F., Perry, G.H. \& Di Rienzo, A. (2010) Evolutionary adaptations to dietary changes. Annual Review of Nutrition 30, 291-314.
Marinho, R.C.N., Nóbrega, R.S.A., Zilli, J.É., Xavier, G.R., Santos, C.A.F., Aidar, S.T., Martins, L.M.V. \& Fernandes-Júnior, P.I. (2014) Field performance of new cowpea cultivars inoculated with eficiente nitrogen-fixing rhizobial strains in the Brazilian Semiarid. Pesquisa Agropecuária Brasileira 49, 395-402.

Mendiola-Olaya, E., Valencia-Jiménez, A., Valdés-Rodríguez, S., Délano-Frier, J. \& Blanco-Labra, A. (2000) Digestive amylase from the larger grain borer, Prostephanus truncatus. Comparative Biochemistry and Physiology 126, 425-433.

Miller, GL. (1959) Use of dinitritosalicylic acid reagent for determination of reducing sugar. Analytical Chemistry 31, 426-442.

Moghadam, N.N., Holmstrup, M., Manenti, T., Mouridsen, M. B., Pertoldi, C. \& Loeschcke, V. (2015) The role of storage lipids in the relation between fecundity, locomotor activity, and lifespan of drosophila melanogaster longevity-selected and control lines. PLOS ONE 10, 1-18.

Ndakidemi, P.A. \& Dakora, F.D. (2003) Legume seed flavonoids and nitrogenous metabolites as signals and protectants in early seedling development. Functional Plant Biology, 30, 729745.

Ndidi, U.S., Ndidi, C.U., Olagunju, A., Muhammad, A., Billy, F. G. \& Okpe, O. (2014) Proximate, antinutrients and mineral composition of raw and processed (Boiled and Roasted) Sphenostylis stenocarpa Seeds from Southern Kaduna, Northwest Nigeria. ISRN Nutrition 280837, 1-9.

Park, J.H. \& Keeley, L.L. (1996) Calcium-dependent action of hypertrehalosemic hormone on activation of glycogen phosphorilase in cockroach fat body. Molecular and Cellular Endocrinology 116, 199-205.

Parra, J.R.P., Panizzi, A.R. \& Haddad, M.L. 2009. Índices nutricionais para medir o consumo e utilização de alimentos por insetos. pp. 37-78 in Panizzi, A.R., Parra, J.R. (Eds). Biotecnologia e nutrição de insetos. Base para manejo integrado de pragas. Embrapa informação tecnológica, Brasília, DF.

SAS Institute. (2002). SAS User's Manual. SAS Institute, Cary.

Silva, L.B., Carvalho, G.S., Mancin, A.C., Silva, L.S., Nóbrega, R. S.A., Pavan, B.E., Maggioni, K. \& Costa, E.M. (2014) Brehavior of Callosobruchus maculatus populations fed with Vigna ungiculata grain cultivated with diazotrophic bacteria strains. Journal of Entomology 11(3), 111-126.

Soares, A.L.L., Pereira, J.P.A.R., Ferreira, P.A.A., Vale, H.M.M. Lima, A.S., Andrade, M.J.B. \& Moreira, F.M.S. (2006) Eficiência agronômica de rizóbios selecionados e diversidade de populações nativas nodulíferas em Perdões (MG). I caupi. Revista Brasileira de Ciência do Solo 30, 795-802.

Sousa, A.H., Maracajá, P.B., Silva, R.M.A., Moura, A.M.N. \& Andrade, W.G. (2005) Bioactivity of vegetal powders against Callosobruchus maculatus (Coleoptera: Bruchidae) in caupi bean and seed physiological analysis. Revista de Biologia e Ciências da Terra 5, 1519-5228.

Tang, D., Dong, Y., Ren, H., Li, L. \& He, C. (2014) A review of phytochemistry, metabolite changes, and medicinal uses of the common food mung bean and its sprouts (Vigna radiata). Chemistry Central Journal 8, 1-9.

Tavares, M.A.G.C. \& Vendramim, J.D. (2005) Bioatividade da Erva-de-Santa-Maria, Chenopodium ambrosoides L., sobre Sitophilus zeamais Mots. (Coleoptera: Curculionidae). Neotropical Entomology 34, 319-323.

Tolmasky, D.S., Rabossi, A. \& Quesada-Allué, L.A. (2001) Synthesis and mobilization of glycogen during metamorphosis of the medfly Ceratitis capitata. Archives of Biochemistry and Biophysics 392, 38-47.

Titarenko, E., Chrispeels, M.J. (2000) cDNA cloning, biochemical characterization and inhibition by plant inhibitors of the a- 
amylases of the Western corn rootworm, Diabrotica virgifera virgifera. Insect Biochemistry and Molecular Biology, Oxon 30, 979-990.

Wang, J., Li, X., Xia, X., Li, H., Liu, J., Li, Q.X., Li, J. \& Xu, T. (2014) Extraction, purification, and characterization of a trypsin inhibitor from cowpea seeds (Vigna unguiculata). Preparative Biochemistry and Biotechnology 44, 1-15.
Willmer, P., Stone, G. \& Johnston, I. (2005) Environmental Physiology of Animals. 2nd edn. Blackwell Publishing, Malden, MA. 754p.

Zavala, J.A., Patankar, A.G., Gase, K., Hui, D. \& Baldwin, I.T. (2004) Manipulation of endogenous trypsin proteinase inhibitor production in Nicotiana attenuate demonstrates their function as antiherbivore defenses. Plant Physiology 134, 1181-1190. 